\title{
Characterization of an Ohio Isolate of Brome Mosaic Virus and Its Impact on the Development and Yield of Soft Red Winter Wheat
}

\author{
B. A. Hodge, ${ }^{1}$ J. D. Salgado, ${ }^{1}$ P. A. Paul, ${ }^{1}$ and L. R. Stewart ${ }^{2 \dagger}$ \\ ${ }^{1}$ Department of Plant Pathology, The Ohio State University, Ohio Agricultural Research and Development Center, Wooster, OH \\ 44691; and ${ }^{2}$ U.S. Department of Agriculture Agricultural Research Service, Corn, Soybean, and Wheat Quality Research Unit, \\ Wooster, OH 44691
}

\begin{abstract}
Brome mosaic virus (BMV) is generally thought to be of little economic importance to crops; consequently, there is little information about its impact on wheat production under field conditions. After repeated detection of BMV in Ohio wheat fields at incidences up to $25 \%$, the virus was isolated, sequenced, characterized, and tested for its impact on soft red winter wheat (SRWW). The Ohio isolate of brome mosaic virus (BMV-OH) was found to be $>99 \%$ identical to a BMV-Fescue isolate (accession no. DQ530423-25) and capable of systemically infecting multiple monocot and dicot species, including cowpea and soybean, in experimental inoculations. BMV-OH was used in field experiments during the 2016 and 2017 growing seasons to quantify its effect on SRWW grain yield and

development when inoculated at Feekes 1, 5, 8, and 10 in two to four cultivars. Cultivar and timing of inoculation had statistically significant $(P<$ $0.05)$ main and interaction effects on grain yield, wheat growth, and multiple components of yield. Compared with noninoculated controls, BMV-OH reduced grain yield by up to $61 \%$ when inoculated at Feekes 1 and by as much as 25,36 , and $31 \%$ for inoculations at Feekes 5, 8, and 10 , respectively. The magnitude of the yield reduction varied among cultivars and was associated with reductions in grain size and weight or plant population. These findings suggest that BMV could impact wheat productivity in Ohio and will serve as the basis for more large-scale investigations of the effects of this virus in commercial fields.
\end{abstract}

Wheat (Triticum aestivum) is one of the leading crops that is produced, consumed, and traded globally, second only behind corn (Oleson 1996; USDA ERS 2018). In the United States, wheat is the third most widely cultivated field crop behind corn and soybean in terms of hectares planted. It accounted for $\$ 8.1$ billion in production value in 2017, and it is primarily used for domestic food products or export (USDA NASS 2018). However, low productivity and profitability have led to a decline in the number of hectares planted to wheat in the United States (USDA NASS 2018). Both abiotic and biotic causes of disease can lead to reduced yield, further contributing to the relatively low profitability of the crop. Potential yield-reducing biological stresses, the impact of which is often overlooked and underestimated, are caused by viruses. This is partly because virus-related problems in wheat are often misdiagnosed as results of abiotic stresses, such as nutrient deficiency (Carrigan et al. 1981). On a regional basis, virus diseases are estimated to cause 7 to $10 \%$ yield reduction in wheat every year, although some viruses, like wheat streak mosaic virus (WSMV), can reduce yield by $>60 \%$ in fields with early infection and high severity and incidence (Brakke 1987). In the United States, the major known viruses include barley

${ }^{\dagger}$ Corresponding author: L. R. Stewart; lucy.stewart@ars.usda.gov

Funding: This work was funded by the Ohio Small Grains Marketing Program, the Ohio Agricultural Research and Development Center SEEDS industry grant program, the U.S. Department of Agriculture Agricultural Research Service, and The Ohio State University Department of Plant Pathology. Salaries and research support for B. A. Hodge and P. A. Paul were provided by state and federal funds to the Ohio Agricultural Research and Development Center.

*The $\boldsymbol{e}$-Xtra logo stands for "electronic extra" and indicates that three supplementary figures and one supplementary table are published online.

The author(s) declare no conflict of interest.

Accepted for publication 9 October 2018.

This article is in the public domain and not copyrightable. It may be freely reprinted with customary crediting of the source. The American Phytopathological Society, 2019 yellow dwarf virus (BYDV), cereal yellow dwarf virus, WSMV, soilborne wheat mosaic virus (SBWMV), wheat yellow mosaic virus, triticum mosaic virus, High Plains wheat mosaic virus (HPWMoV), and wheat spindle streak mosaic virus (WSSMV) (Brakke 1987; Byamukama et al. 2016; Miller and Rasochová 1997; Velandia et al. 2010).

In the United States, Ohio is one of the leading producers of soft red winter wheat (SRWW), an important component of a soybeanwheat-corn rotation in the Midwest (Barker et al. 2017). However, low profitability and incentives to produce barley have led to a decline in the number of hectares planted to wheat in Ohio (Turner and Morris 2017). Although most modern SRWW cultivars have the genetic potential to yield in excess of $6.7 \mathrm{MT} \mathrm{ha}^{-1}$, warm, wet late-spring and early-summer conditions often shorten the grain fill period and favor the development of diseases, reducing the state average yield to $\sim 4.7 \mathrm{MT} \mathrm{ha}^{-1},>30 \%$ below the yield potential (Campbell and Lafever 1977; Green et al. 2012; USDA-NASS 2017). Although agronomic practices and pest and disease management have helped to increase yields and minimize losses (Richer and Lindsey 2016; Salgado et al. 2017), attainable yields remain low and highly variable among years and locations (Lackermann et al. 2011; Lee and Herbek 2012).

Results from surveys of Ohio wheat fields conducted in 2012 and 2016 showed that several viruses, including brome mosaic virus (BMV), were detected in 32 to $95 \%$ of wheat fields tested (Hodge et al. 2017). The species BMV is the type member of the genus Bromovirus, family Bromoviridae, and it has a tripartite, positive sense RNA genome (Ahlquist et al. 1984). During the 2012 and 2016 surveys, BMV was detected in 22 of 67 fields sampled, with an incidence of up to $25 \%$ within fields measured by enzyme-linked immunosorbent assay (ELISA) from field transect samples (Hodge et al. 2017). Before our 2012 and 2016 surveys, BMV was detected in Ohio in 1990 in weedy grass species and sweet corn samples (Louie and Knoke 1991). This virus has an extraordinarily wide host range that includes $>50$ genera in the genus Poaceae, Nicotiana benthamiana, soybean (Glycines max), and cowpea (Vigna unguiculata) (Díaz-Cruz et al. 2017; Haber 1989; Trzmiel et al. 2016), causing host-dependent symptoms, including foliar mosaic, stunting, chlorosis, local lesions, and necrosis (Mian et al. 2005; Slykhuis 1976).

BMV is widely distributed globally, and it has been reported in the United States, Canada, South Africa, Russia, Poland, 
Czechoslovakia, Estonia, Great Britain, and Finland (Díaz-Cruz et al. 2017; Gibson and Kenten 1978; Lane 1974; Mian et al. 2005; Sõmera et al. 2016; Tošić 1971; Trzmiel et al. 2016; Urbanavičienè and Žižytė 2012; Von Wechmar and Barbara Van Regenmortel 1966). It is considered to be primarily mechanically transmitted in the field (Lane 1974; Mian et al. 2005), but seed transmission (Von Wechmar et al. 1984) and low rates of transmission by flea beetle (Altica foliaceae), cereal leaf beetle (Oulema melanopus), dagger nematode (Xiphinema spp.), bird cherry-oat aphid (Rhopalosiphum padi), and Russian wheat aphid (Diuraphis noxia) have been described in greenhouse experiments with wheat or barley as hosts (Damsteegt et al. 1992; Gáborjányi and Szabolcs 1987; Rybicki and Wechmar 1982; Srivatsavai 2005). In addition, a previous report of infectious BMV particles in irrigation runoff from cereal fields suggested the possibility of mechanical soil transmission (Jeżewska et al. 2018).

$\mathrm{BMV}$ is a model for RNA virus biology, being one of the most comprehensively investigated positive sense RNA viruses (Ahlquist 1992; Kao and Sivakumaran 2000; Lucas et al. 2002; Scholthof et al. 2011). However, despite the plethora of information on its basic biology (Ahlquist and Janda 1984; Ahlquist et al. 1984; Ding et al. 2006; Janda and Ahlquist 1993), it is not considered a major pathogen, and there is currently very little information available regarding its impact on crop production. This lack of information is partly owing to BMV being widely regarded as having little economic impact on crops, such as wheat (Kao and Sivakumaran 2000; Lane 1974; Scholthof et al. 2011). However, reports of high disease incidence in some fields and results from controlled environment studies suggest otherwise. For example, BMV was detected in wheat fields at up to $44 \%$ incidence in Hungary in 1995 and 13\% in Alabama in 2004 (Papp et al. 1996; Srivatsavai 2005), and results from greenhouse studies indicated that it reduced wheat height, weight, and yield components (kernel size and weight) (Pocsai 1987; Tošić 1971). Similarly, Mian et al. (2005) showed that BMV reduced fescue height and yield.

The prevalence of BMV in Ohio and results from previous greenhouse studies have led us to hypothesize that this virus could be affecting wheat productivity in commercial fields. To test this hypothesis, the Ohio isolate of brome mosaic virus (BMV-OH) from wheat was sequenced and utilized in inoculated field experiments to assess its impact on SRWW growth and grain yield. Plots of different cultivars were inoculated at early (Feekes 1, 2, and 5) and late (Feekes 8 and 10) growth stages and rated for BMV incidence, plant height, stand establishment, grain yield, and several yield components. Findings from this study will be invaluable for assessing the potential impact of this disease on grain and straw yield and seed quality, all of which are important for wheat production as a commodity in Ohio and other states in the Midwest.

\section{Materials and Methods}

Virus isolation and reverse transcription polymerase chain reaction detection. $\mathrm{BMV}-\mathrm{OH}$ was isolated from wheat collected in Henry County, Ohio exhibiting mosaic and stunting symptoms and detected using a previously described reverse transcription polymerase chain reaction (RT-PCR) protocol (Stewart et al. 2014) using primers LRS 495/496 (Supplementary Table S1). The virus was transmitted and isolated from other viruses by grinding symptomatic tissue in $\mathrm{KPO}_{4}$ buffer $(0.01 \mathrm{M}$ potassium phosphate, $\mathrm{pH} 7)$ and rub inoculating serially diluted plant sap onto 7-day-old plants of SRWW cultivar Freedom. Plant extract from the symptomatic plants was diluted $1 / 500$ for each passage and subjected to hot water bath treatment of $65^{\circ} \mathrm{C}$ for $15 \mathrm{~min}$ before inoculation to select for BMV particles, because they are more heat stable than other mechanically transmissible wheat-infecting viruses (Hamilton 1961). After symptom development, inoculated plants were tested for BMV and potential coinfecting viruses, including WSMV (LRS 127/128), SBWMV (LRS 129/130), barley stripe mosaic virus (LRS 139/140), and WSSMV (LRS 125/126), following an RT-PCR protocol with template-specific diagnostic primers. After RT-PCR, this process was repeated until only BMV was detected in the inoculated plants over three inoculation passages.
BMV was detected in tissue by grinding $1 \mathrm{~g}$ of tissue in $4 \mathrm{ml}$ of filter-sterilized $0.02 \mathrm{M}$ sodium carbonate buffer, $\mathrm{pH} 7$, with $2 \%$ polyvinylpyrrolidone, $0.2 \%$ bovine serum albumin (BSA), and $0.05 \%$ Tween-20. Aliquots of $4 \mu \mathrm{l}$ from this extract were added to $50 \mu \mathrm{l}$ of $0.1 \mathrm{M}$ glycine- $\mathrm{NaOH}, \mathrm{pH} 9.0,50 \mathrm{mM} \mathrm{NaCl}, 1 \mathrm{mM}$ (ethylenedinitrilo)tetraacetic acid, $0.5 \%$ Triton X-100, $1 \% \beta$-mercaptoethanol, and $5 \% \mathrm{BSA}$ and incubated at $95^{\circ} \mathrm{C}$ for $10 \mathrm{~min}$; then, they were placed on ice for $5 \mathrm{~min}$. An aliquot of $1.5 \mu \mathrm{l}$ extract was then added to a one-step RT-PCR reaction with GoTaq (Promega Corp., Madison, WI), Superscript III polymerase, and RNaseOUT (ThermoFisher Scientific, Waltham, WA) with forward and reverse primers and primer pair-specific annealing temperatures. After first-strand synthesis at $50^{\circ} \mathrm{C}$ for $40 \mathrm{~min}$ and 35 cycles of polymerase chain reaction $\left(\mathrm{PCR} ; 94^{\circ} \mathrm{C}\right.$ for $15 \mathrm{~s}, 55^{\circ} \mathrm{C}$ for $20 \mathrm{~s}$, and $72^{\circ} \mathrm{C}$ for $30 \mathrm{~s}$ ), samples were analyzed by gel electrophoresis on $1 \%$ agarose gels.

Host range testing and DAS-ELISA. BMV-OH was subjected to a partial host range study under greenhouse conditions to determine plant species that BMV-OH can infect. Wheat (cultivars Hopewell and Truman), oats (Avena sativa Armour), sorghum (Sorghum bicolor cultivars Atlas and Sart), barley (Hordeum vulgare; cultivar unknown), rye (Secale cereale), corn (Zea mays cultivars Spirit and Early Sunglow), cowpea (cultivars Brown Crowder and Cream), soybean (cultivars Sloan and Wyandot), quinoa (Chenopodium quinoa cultivar White Mountain), and N. benthamiana were planted in $15-\mathrm{cm}$ pots with five plants per pot. The pots were arranged in a randomized complete block design with three replicates, with each block containing a pot of each cultivar that was virus inoculated and a pot that was noninoculated. The experiment was performed once. For inoculation, wheat tissue infected with the BMV-OH isolate was ground in $\mathrm{KPO}_{4}$ buffer at a ratio of $1 \mathrm{~g}$ to $5 \mathrm{ml}$ of buffer containing $0.1 \%$ carborundum and rub inoculated onto the first true leaves of each plant after emergence (quinoa was inoculated when the plants had 7 to 10 mature leaves). An additional group of potted plants of each species was left noninoculated to serve as a reference against which inoculated plants were compared. At 14 days after inoculation, noninoculated leaves were collected from each inoculated plant and subjected in two technical replicates (pipetting replicates from the same biological sample) to DAS-ELISA using a kit from Agdia Inc. (Elkhart, IN) to determine the presence of BMV. Corn and quinoa were not subjected to ELISA: corn became necrotic and died after virus inoculation, leaving no testable tissue, and local lesions but no systemic infections were observed in quinoa. The noninoculated plants of each cultivar were pooled by replicate and also subjected to ELISA. The average absorbance values at $405 \mathrm{~nm}$ from each plant were compared with noninoculated healthy controls of the same host species (or cultivar where applicable). Plants were considered systemically infected if the rate of change in average absorbance value at $405 \mathrm{~nm}$ was at least twice that of the healthy control and if the average absorbance value at $405 \mathrm{~nm}$ was greater than the average absorbance value of the healthy control plus three times the standard deviation of the healthy control (Todd et al. 2010).

Sequencing BMV genome. Volunteer wheat exhibiting stunting and mosaic symptoms was collected from the Northwest Agricultural Experiment Station in Custar, Ohio in April 2016. HPWMoV and BMV were detected from the tissue using previously described protocols (Stewart et al. 2013, 2014). The tissue sample was subjected to a nonspecific virion purification as previously described (Louie et al. 2006; Shepherd et al. 1987). Total RNA was then extracted from the virion suspension using a Directzol RNA miniprep kit (Zymo Research, Irvine, CA) using the provided protocol. Total RNA was sequenced using protocols previously described (Stewart et al. 2014), with some modifications. Adapter-ligated cDNA libraries were prepared using the Illumina Plant RiboZero rRNA removal kit (Illumina, San Diego, CA) following the manufacturer's protocol. The cDNA was pooled with other samples to generate a multiplexed cDNA library as previously described (Stewart et al. 2014). The cDNA library was sequenced on one lane of a Dual-Lane Rapid Flow Cell using HiSeq 2500 to obtain paired end 
100-bp reads (The James Comprehensive Cancer Center, Columbus, $\mathrm{OH}$ ).

Approximately 21.5 million sequenced reads were analyzed using CLC Genomics Workbench 11 (Qiagen, Redwood City, CA) following a previously described pipeline (Stewart et al. 2014) and a custom plant virus database prepared following that protocol using virus sequences downloaded from the NCBI on 1 December 2016. After removal of reads that aligned to the wheat genome (Assembly TGAC1, Earlham Institute) (Mayer et al. 2014), 17.7 million reads were used for de novo assembly; $\sim 15.8$ million reads were assembled into nine near-complete contigs of BMV RNA 1, 2, and 3, with three contigs of $>99 \%$ nucleotide identity assembling per RNA segment in an assembly of contigs in Sequencher (Gene Codes, Ann Arbor, MI) (Supplementary Fig. S1).

Total RNA was extracted from wheat infected with passaged and isolated BMV-OH as previously described. RT-PCR was conducted using a Superscript III First Strand Synthesis kit, PrimeSTAR HS DNA Polymerase (Takara Bio USA, Mountain View, CA), and template-specific primers. The PCR products were directly Sanger sequenced using both forward and reverse primers (Eurofins Genomics LLC, Louisville, KY). Rapid amplification of cDNA ends (RACE) was conducted for both the $5^{\prime}$ and $3^{\prime}$ ends of each RNA segment using a 3' RACE System for Rapid Amplification of cDNA Ends kit (ThermoFisher Scientific, Waltham, WA) and following a previously described protocol for 5' RACE (Green et al. 2012). Nested PCR was conducted using Q5 2x PCR Master Mix (New England Biolabs, Ipswich, MA) as described by the RACE protocols using template-specific primers, and the PCR products were ligated into the pMiniT vector (New England Biolabs, Ipswich, MA). The plasmids were Sanger sequenced using the included vector kit primers. The BMV-OH sequence used in this study was derived from a consensus sequence of an assembly of the three RNA-Seq contigs of each RNA segment and the Sanger sequencing built using Sequencher DNA Sequence Analysis Software (Gene Codes Corporation, Ann Arbor, MI). Alignments and pairwise comparison of BMV-OH, BMV-Fescue (DQ530423-25), and BMV-M2 (AB183261-63) nucleotide and amino acid sequences were conducted using MacVector (MacVector Inc., Apex, NC).

Field experiments. Plot establishment and maintenance. Field experiments were conducted at the Snyder Farm of The Ohio Agricultural Research and Development Center located near Wooster, Ohio during the 2015 to 2016 and 2016 to 2017 growing seasons. Both experiments were established in fields previously rotated to oats, and they were managed and maintained according to standard agronomic practices for Ohio (Barker et al. 2017). On 8 October 2015 and 5 October 2016, 1.5-m-wide strips of SRWW cultivars were planted as primary main plots in replicated blocks, with 1.5-m-wide border strips of the cultivar Malabar planted between adjacent main plots (2016 only) and 1.5-m-wide border strips of rye between blocks and around the entire field (experimental design described below). In each strip, seeds were planted in seven rows at a seeding rate of $4 \times 10^{6}$ seeds per 1 ha.

On 20 April 2016, propiconazole (Tilt 3.6 EC; Syngenta Crop Protection Inc., Greensboro, NC) was applied at $210 \mathrm{~g}$ a.i./ha to all plots to control stripe rust (Puccinia striiformis). On 20 May 2017 (at anthesis; Feekes 10.5.1), all plots were treated with the fungicide tebuconazole + prothioconazole (Prosaro 421 SC; Bayer Cropscience, Research Triangle Park, NC) at $100 \mathrm{~g}$ a.i./ha of each active ingredient to suppress Fusarium head blight (FHB; Fusarium graminareum), and on 30 May 2017, they were treated with Mustang Maxx insecticide (FMC Agricultural Solutions, Philadelphia, PA) at $5 \mathrm{~g}$ a.i./ha to control cereal leaf beetle. Weather conditions during the experiments were monitored using a weather station operated by the National Oceanic and Atmospheric Administration located on the Snyder Farm, $\sim 25$ to $50 \mathrm{~m}$ from the research plots.

Mean daily temperature varied from $-3.3^{\circ} \mathrm{C}$ to $21.3^{\circ} \mathrm{C}$ during the 2015 to 2016 growing season and from $-1.8^{\circ} \mathrm{C}$ to $22.1^{\circ} \mathrm{C}$ during the 2016 to 2017 season. During the first growing season, there were 23, 67 , and 12 days with a minimum temperature below $0^{\circ} \mathrm{C}$ between October and December, between January and March, and between
April and June, respectively. During the second season, there were 40,55 , and 24 days with a minimum temperature below $0^{\circ} \mathrm{C}$ between October and December, between January and March, and between April and June, respectively.

Experimental design. In 2015 to 2016, the experimental design was a randomized complete block with four replications, a stripplot (or split-block) arrangement of cultivar Cooper (early maturity), Freedom (midseason), Hopewell (midseason), and Truman (late maturity) as primary main plots, and inoculation treatments as secondary main plots. These cultivars were selected to represent the range of maturity times and yield potentials typical of SRWW cultivars grown in Ohio. Alleyways were cut at 6-m intervals across the primary main plots to generate orthogonal strips of secondary main plots to which BMV-OH inoculation treatments were assigned. The secondary main plot treatments were specific growth stages at which the cultivars were inoculated with BMV: Feekes 1 to 2 (30 October 2015), Feekes 5 (16 April 2016), Feekes 8 (7 May 2016), and Feekes 10 (14 May 2016) (Large 1954). A noninoculated strip across the cultivars was left as the control in each block. Each primary $\times$ secondary main plot combination (cultivar $\times$ inoculation treatment combination) was $1.5 \times 6 \mathrm{~m}$. Hereafter, Feekes 1 to $2,5,8$, and $10 \mathrm{BMV}$ inoculation treatments will be referred to as Treatments 1 to 4 , respectively.

In 2016 to 2017, the experimental design was a split plot, with the Hopewell and Truman randomized as main plots in five blocks. Each main plot was then divided into subplots to which the BMV-OH inoculation treatments described above were randomly assigned. However, in 2017, mock inoculations were incorporated into the experimental design by including subplots that were mock inoculated at the same growth stages as the virus-inoculated subplots. Mocks were included to account for any potential effects of mechanical inoculation on measured responses. Separate plots were thus virus and mock inoculated at Feekes 1 to 2 (24 October 2016), Feekes 5 (9 April 2017), Feekes 8 (Hopewell on 25 April 2017 and Truman on 30 April 2017), and Feekes 10 (Hopewell on 30 April 2017 and Truman on 12 May 2017).

Mechanical inoculation. Plastic nursery trays $(50.8 \mathrm{~cm}$ long $\times$ $35.5 \mathrm{~cm}$ wide $\times 7.6 \mathrm{~cm}$ high) were planted with $\sim 500$ seeds of Freedom $\sim 1$ month before the field-planted wheat was anticipated to reach a growth stage targeted for inoculation. Stock wheat plants infected with the BMV-OH isolate were ground up in $0.01 \mathrm{M} \mathrm{KPO}_{4}$ buffer and rub inoculated onto 7- to 10-day-old seedlings in the trays. After inoculation, plants were grown in a greenhouse for 21 to 28 days, harvested at soil level, homogenized in $5 \mathrm{ml} / \mathrm{g}$ of tissue of cold $0.01 \mathrm{M} \mathrm{KPO}_{4}$ buffer, and filtered through cheesecloth. The resulting inoculum was diluted to a ratio of $1 \mathrm{~g}$ of tissue to $30 \mathrm{ml}$ of cold buffer containing $0.1 \%$ carbordundum, immediately taken to the field, and applied to the appropriate plots using a Solo 451 Backpack Mist Blower (Solo Incorporated, Newport News, VA). Inoculum was applied at a rate of 1.12 liters per plot at a maximum blower air volume of $1,400 \mathrm{~m}^{3} / \mathrm{h}$. In 2016 to 2017 , the mockinoculated plots were sprayed at the same rate with $0.01 \mathrm{M} \mathrm{KPO}_{4}$ buffer and $0.1 \%$ carborundum.

Data collection. Wheat growth and stand count. Tiller height and stand count were estimated after Feekes 10.5.4 as measures of BMV effect on wheat growth and development, important components of both grain and straw yield. Tiller height was measured as the height of the tiller from the ground to the collar of the flag leaf on 20 randomly selected primary tillers per plot. Stand count was estimated as the mean number of tillers within a 1 -foot $(0.305-\mathrm{m})$ section of a row (a cluster) at five arbitrarily selected sites within each plot. Tillers were counted in each cluster as described by Kriss et al. (2012) and then, converted to tillers per meter of row by multiplying by 3.28 .

BMV incidence of infection. On 6 June 2016 and 30 May 2017 (between Feekes 10.5.1 and 10.5.5), seven leaves were collected at five arbitrarily selected sites (clusters) per plot. Sap from each individual leaf piece was rubbed onto a nitrocellulose membrane and subjected to a tissue blot immunoassay (Chang et al. 2011) using antisera previously generated (Louie and Knoke 1991) following a previously 
described protocol (Louie et al. 1982). Sap from both known BMVinfected plants and healthy plants was rubbed onto each blot as controls. Individual leaf pieces were considered positive if the blot changed color relative to the healthy controls. Incidence of infection was quantified as the proportion of positive leaves (the number of positive samples divided by the total number of samples, which was 35 in most cases).

Grain yield and quality traits. Plots were harvested between early and mid-July using an ALMACO SPC20 (ALMACO, Nevada, IA) research plot combine harvester. The harvester provided measurements of yield (bushels per acre), test weight (pounds per bushel), and grain moisture. Yield was adjusted to $13.5 \%$ grain moisture and converted to kilograms per hectare based on a standard bushel weight of $27 \mathrm{~kg}$ per bushel. Test weight was converted to kilograms per cubic meter. During harvest, grain samples were collected from each plot and later assessed for Fusarium-damaged kernels (FDKs; a visual measure of the damaged caused by FHB in terms of the percentage of shriveled, lightweight, and pinkish-white kernels in a sample) as previously described (Salgado et al. 2011) and thousand-seed weight (TSW). Kernel diameter was also estimated using a Single Kernel Characterization System (SKCS 4100; Perten Instruments North America Inc., Springfield, IL) at the Soft Red Winter Wheat Quality Lab in Wooster, Ohio.

Data analysis. Linear mixed model analysis of variance. Data were analyzed using PROC GLIMMIX in SAS (SAS Inc., Cary, NC) to evaluate the effects of cultivar, inoculation treatments, and their interaction on all measured responses (Littell et al. 2006). Response and year were analyzed separately, with cultivar, inoculation treatment, and their interaction treated as fixed effects and block, block by cultivar (2016 and 2017), and block by treatment interactions (2016 only) treated as random effects. Before fitting the model, percentage incidence was arcsine square root transformed to stabilize variance.

Linear mixed model covariance analysis. For all measured grain yield and quality responses (yield, test weight, kernel diameter, and thousand-kernel weight) known to be affected by FHB (Salgado et al. 2015), percentage FDK was included in the models fitted to the 2016 data as a continuous covariate to adjust for the effect of FHB. Models were fitted with the same fixed and random effects terms described above as well as terms for two- and three-way interactions between the fixed effects and the covariate. Nonsignificant interaction terms were subsequently removed before fitting the final models. Because FHB levels were very low in 2017 (FDK ranged from 0 to 4\%, with $80 \%$ of the values $<1 \%$ ), there was no need to adjust for the effects of this disease on grain yield, test weight, or other yield components.

Generalized linear mixed model analysis. Because tiller count was assumed to have a conditional Poisson distribution, PROC GLIMMIX of SAS (Littell et al. 2006) was used to fit a generalized linear mixed model to the log link function of this response as previously described (Gbur et al. 2012; Stroup 2013). After fitting the models, means were compared on the link scale, but estimates of mean stand counts as well as their standard errors are presented on the original data scale to facilitate interpretation of the results.

Comparison of main and interaction effects. For all of the analyses described herein, main and interaction means were compared based on $t$ tests using lsmeans and lsmestimate statements in PROC GLIMMIX, with the cl option used to obtain estimates of the $95 \%$ confidence intervals around means and mean differences. Differences were considered statistically significant at $P<0.05$. In both years, virus-inoculation treatment means were compared with the noninoculated controls across and within cultivars depending on the statistical significance of the treatment by cultivar interaction. Preliminary analyses of the data collected in 2017 showed that the mock-inoculated treatments were not significantly different from the noninoculated controls for any of the measured responses; therefore, only the noninoculated controls were used as references for comparison.

\section{Results}

Sequencing and host range of the BMV-OH isolate. The BMV$\mathrm{OH}$ isolate genome was deposited in GenBank under accession numbers MH025765 (RNA 1), MH025766 (RNA 2), and MH025767 (RNA 3). The nucleotide sequences of these segments were $>99 \%$ identical to those of the U.S. BMV-Fescue isolate (DQ530423-25) and 96.9 to $99 \%$ identical to other complete BMV sequences in the database, including BMV-CZ (GU584129-31), BMV-M2 (AB183261-63), BMV-KU1 (X458456-58), BMV-M1 (X02380; X01678, and J02042), and BMV-Estonia (KU726253-55). The nucleotide and amino acid sequences were $100 \%$ identical for ORF $3 \mathrm{a}$ (movement protein) and ORF $3 \mathrm{~b}$ (coat protein) between the $\mathrm{BMV}-\mathrm{OH}$ and BMV-Fescue isolates. Notably, the BMV-OH and BMV-Fescue isolates share two of four amino acid substitutions (S89P and T299S) in the movement protein that, in BMV-M2, are reported to be required for systemic infection of cowpea (De Jong and Ahlquist 1995). The greatest differences between the two isolates across the genome were in noncoding regions, and only a few amino acid coding variations were found in ORF1a (replicase associated protein) and ORF2a (RNA-dependent RNA polymerase).

BMV-OH induced mosaic symptoms and was detected in $100 \%$ of wheat, rye, barley, and oat plants that were inoculated. All inoculated corn plants developed systemic necrosis, leading to total plant death 5 days after inoculation, which is characteristic of certain maize lines inoculated with BMV (Ding et al. 2001; Lane 1974). Across the three replicates, BMV was detected in $100 \%$ of sorghum plants tested, but symptoms were not observed in all plants. Mosaic symptoms were observed in $100 \%$ (15 of 15) of the inoculated plants of Atlas, but only $27 \%$ (4 of 15) of the inoculated plants of Sart. N. benthamiana did not develop symptoms, but BMV was detected in noninoculated tissue. The quinoa developed 2- to 3-mm chlorotic spots (local lesions) on the inoculated leaves, such as is characteristic for BMV in this previously described local lesion host (Rao and Grantham 1995). In cowpea, BMV was detected in new leaves that emerged after inoculation in $60 \%$ of the plants ( 9 of 15) of Brown Crowder and $53 \%$ of the plants ( 8 of 15) of Cream. The newly emerged leaves of cowpea plants in which BMV was detected were shriveled, with veinal chlorosis and mottling symptoms, whereas plants in which BMV was not detected had large green leaves similar to the noninoculated plants. In soybean, BMV was detected in new noninoculated leaves of both Sloan ( 7 of 15 plants) and Wyandot (10 of 15 plants) that emerged after inoculation. These BMV-positive leaves were small and developed chlorotic spots, which were not observed on plants in which BMV was not detected or in the controls.

Overview of growing conditions, BMV symptom development, and incidence of infection. In both growing seasons, all plots inoculated with BMV-OH at Feekes 1 to 2 (Treatment 1) showed mosaic symptoms (Supplementary Fig. S2). In plots inoculated at Feekes 5 (Treatment 2), chlorosis was observed on the flag leaves at Feekes 8 to 9 (Supplementary Fig. S3) but not in noninoculated plots, mock-inoculated plots (in 2017), or plots inoculated at the other growth stages. Chlorosis observed in plots inoculated at Feekes 5 was visually more intense and widespread in Hopewell and Cooper than Truman and Freedom. Plots inoculated at Feekes 8 and 10 (Treatments 3 and 4) showed no foliar symptoms distinguishable from the control plots. Mosaic symptoms were observed uniformly across all plots of the experiment between Feekes 5 and 9. These symptoms were attributed, after RT-PCR analysis with primers LRS125/126, to natural infection of the plants with WSSMV detected in both BMV-inoculated and noninoculated plots. No plants tested positive for WSSMV in 2017.

Results from linear mixed model analysis of the effects of cultivar, inoculation timing, and their interaction on arcsine-transformed BMV incidence are summarized in Table 1. Mean incidence (percentage of flag leaf samples testing positive for BMV by tissue blot immunoassay) varied among cultivars, inoculation treatments, and growing seasons. In virus-inoculated plots, incidence ranged from 58 to $70 \%$ for Cooper, from 55 to $88 \%$ for Freedom, from 80 to 98\% for Hopewell, and from 21 to $61 \%$ for Truman in 2016 and from 61 to $95 \%$ for Hopewell and from 44 to $89 \%$ for Truman in 2017. In 
2016, the main effects of cultivar and inoculation treatment on incidence (on the arcsine-transformed scale) were statistically significant $(P<0.05)$, but the interaction was not $(P=0.190)$ (Table 1$)$. Inoculated plots of all cultivars had significantly higher mean incidence than their respective noninoculated checks. Averaged across all inoculation treatments, Cooper, Hopewell, and Freedom all had significantly higher mean incidence rates than Truman $(P<0.05)$. There was a trend toward higher mean incidence for Treatment 1 , but differences between pairs of inoculation treatment means were not statistically significant $(P>0.05)$.

In 2017, the inoculation treatment main effect and cultivar by inoculation treatment interaction effect were statistically significant $(P<0.05)$ (Table 1$)$, whereas cultivar main effect was marginally significant $(P=0.063)$. For both Hopewell and Truman, inoculated plots again had significantly higher mean arcsine-transformed incidence than the control, with the highest mean observed from Treatment 1. Among inoculation treatments, Treatment 4 for Hopewell and Treatments 2 and 3 for Truman had significantly lower mean incidence rates than Treatment 1 . The difference in meantransformed incidence between Hopewell and Truman was only statistically significant when plots were inoculated at Feekes 8 (Treatment 3).

BMV-OH effect on wheat growth and development. Averaged across blocks, mean tiller height (measured from the ground to the ligule of flag leaf) varied among inoculation treatments, ranging from 61 to $69 \mathrm{~cm}$ for Cooper, from 62 to $70 \mathrm{~cm}$ for Freedom, from 62 to $71 \mathrm{~cm}$ for Hopewell, and from 71 to $72 \mathrm{~cm}$ for Truman in 2016 and from 53 to $73 \mathrm{~cm}$ for Hopewell and from 62 to $74 \mathrm{~cm}$ for Truman in 2017. The main and interaction effects of cultivar and inoculation treatment on tiller height were statistically significant in both years $(P<0.01)$ (Table 1). In 2016, the inoculation treatment effect on height was statistically significant $(P<0.001)$ for Cooper, Freedom, and Hopewell but not for Truman, whereas in 2017, this effect was statistically significant $(P<0.001)$ for both Hopewell and Truman. In all cases with a statistically significant inoculation treatment effect, the greatest reduction in height relative to the noninoculated control was observed for Treatment 1 (plots inoculated in the fall at Feekes 1 to 2 ). For instance, for Treatment 1 , mean plant height was reduced in Cooper, Freedom, and Hopewell by 10 to $11.5 \%$ in 2016 (for simplicity, only means for Hopewell and Truman are shown in Fig. 1A). In 2017, mean height for Treatment 1 was reduced in both Hopewell and Truman, but the magnitude of height reduction was greater for Hopewell (Fig. 1B).

In both years, very similar results were observed in terms of differences in mean tiller height between cultivars at each level of the inoculation treatment. The effect of cultivar on height was not statistically significant in noninoculated plots $(P=0.29$ in 2016 and $P=0.88$ in 2017), indicating that all cultivars used in this study had similar tiller height when not infected by BMV. However, the cultivar effect was highly or marginally significant when plots were inoculated at Feekes 1 to $2(P<0.001$ in both years), Feekes 5 ( $P<$ 0.001 in both years), Feekes $8(P=0.002$ in 2016 and $P=0.057$ in 2017), or Feekes 10 ( $P=0.059$ in 2016 and $P=0.048$ in 2017). The growth of Truman was the least affected by BMV-OH at each growth stage inoculated, with significantly taller plants than the other cultivars $(P<0.05)$, particularly in plots inoculated before Feekes 10 . However, Cooper was the most severely affected, with significantly shorter plants than Truman in all inoculated plots $(P<0.05)$.

Plant population (stand count) based on mean tiller count per meter of row varied among inoculation treatments and between growing seasons, ranging from 132 to 159 for Cooper, from 104 to 140 for Freedom, from 94 to 131 for Hopewell, and from 100 to 117 for Truman in 2016 and from 75 to 137 for Hopewell and from 77 to 106 for Truman in 2017. Based on results from generalized linear mixed model analyses of the stand count data, the main effects of cultivar and inoculation treatment were statistically significant in both years $(P<0.05)$ (Table 1$)$, whereas the interaction effect was only statistically significant in 2017. In all cases, the only statistically significant stand reduction occurred from Treatment 1. In 2016, stands were 15, 12, 20, and 14\% lower for Cooper, Freedom, Hopewell, and Truman, respectively, for Treatment 1 plots compared with their respective noninoculated controls (for simplicity, only means for Hopewell and Truman are shown in Fig. 1C). Similarly, in 2017, stand counts were 43 and 26\% lower in Treatment 1 plots compared with noninoculated controls for Hopewell and Truman, respectively (Fig. 1D). In both years, pairwise differences between Treatment 2, 3, and 4 and the control were not statistically significant $(P>0.05)$ for any of the cultivars.

Effects of BMV inoculation on yield and yield components. Summary statistics from linear mixed model analyses of the effects of cultivar, timing of inoculation, and their interaction on grain yield, test weight, thousand-kernel weight, and kernel diameter are presented in Table 2. For grain yield, main and interaction effects were statistically significant in both years $(P<0.05)$ (Table 2$)$. Averaged across blocks, mean grain yield ranged from 5,286 to $6,047 \mathrm{~kg} / \mathrm{ha}$ for Cooper, from 4,182 to $5,345 \mathrm{~kg} / \mathrm{ha}$ for Freedom, from 4,229 to $5,512 \mathrm{~kg} / \mathrm{h}$ a for Hopewell, and from 5,206 to 5,691 kg/ha for Truman in 2016 and from 2,094 to 5,458 kg/ha for Hopewell and from 2,741 to $4,826 \mathrm{~kg} / \mathrm{ha}$ for Truman in 2017 . Inoculated plots of all four cultivars in 2016 had significantly lower mean yield than their respective noninoculated checks. However, the magnitude of the yield difference varied among inoculation treatments and cultivars (hence, the statistically significant interaction). Virus inoculation reduced yield by 7 to $26 \%$ relative to the noninoculated control across inoculation treatments by cultivar combinations. For Hopewell, Freedom, Cooper, and Truman, the specific magnitudes of yield reduction across inoculation treatments ranged from 20 to $26 \%$, from 16 to $22 \%$, from 11 to $17 \%$, and from 7 to $9 \%$, respectively (in Fig. 2A, only means for Hopewell and Truman are shown). With a few exceptions, primarily for Freedom, contrasts between pairs of inoculation treatments per cultivar were not statistically significant.

In 2017 , the interaction effect was manifested as differences in both the magnitude and the significance of inoculation treatment effects within and between the two cultivars. For Hopewell, results were comparable with those observed in 2016, with all inoculated plots having significantly lower mean grain yields than the noninoculated control. However, for Truman, although all inoculated plots had numerically lower mean yields than the noninoculated control, the difference was only statistically significant for Treatments 1 and 3 . Virus inoculation reduced mean yield by 1 to $62 \%$ across cultivar by inoculation treatment combinations. Treatment 1 led to the

Table 1. $F$ statistics and probability values from linear mixed model analyses of the effects of wheat cultivar and brome mosaic virus (BMV) inoculation treatment on measures of soft red winter wheat growth and development and BMV infection from field experiments conducted in Ohio during the 2016 and 2017 growing seasons

\begin{tabular}{|c|c|c|c|c|c|c|}
\hline \multirow[b]{2}{*}{ Year and factors $\mathrm{s}^{\mathrm{a}}$} & \multicolumn{2}{|c|}{ Incidence ${ }^{b}$} & \multicolumn{2}{|c|}{ Plant height ${ }^{\mathrm{c}}$} & \multicolumn{2}{|c|}{ Tiller count ${ }^{c}$} \\
\hline & $F$ & $P$ value & $F$ & $P$ value & $\boldsymbol{F}$ & $P$ value \\
\hline \multicolumn{7}{|l|}{2016} \\
\hline VAR & 13.65 & 0.001 & 15.44 & 0.001 & 15.92 & 0.001 \\
\hline TRT & 13.76 & $<0.001$ & 9.06 & 0.001 & 7.93 & 0.001 \\
\hline $\mathrm{VAR} \times \mathrm{TRT}$ & 1.45 & 0.190 & 2.87 & 0.007 & 1.44 & 0.192 \\
\hline \multicolumn{7}{|l|}{2017} \\
\hline VAR & 6.55 & 0.063 & 180.64 & $<0.001$ & 46.85 & 0.002 \\
\hline TRT & 29.55 & $<0.001$ & 37.54 & $<0.001$ & 30.13 & $<0.001$ \\
\hline $\mathrm{VAR} \times \mathrm{TRT}$ & 3.26 & 0.024 & 4.02 & 0.009 & 3.84 & 0.012 \\
\hline
\end{tabular}

a VAR indicates soft red winter wheat cultivars that were tested in the experiments, and TRT indicates the growth stage of virus inoculation, including the noninoculated check.

${ }^{\mathrm{b}}$ Measure of BMV infection. Incidence indicates the percentage of flag leaf samples testing positive for BMV by tissue blot immunoassay. Models were fitted to arcsine square root-transformed incidence.

${ }^{\mathrm{c}}$ Measures of crop growth. Plant height indicates the measured height from the ground to the collar of the flag leaf of primary tillers (in centimeters), and tiller count indicates the number of tillers per meter of row. Models were fitted to the log link function of tiller count assuming a conditional Poisson distribution. 
greatest yield reduction in both Hopewell and Truman: 61 and $43 \%$, respectively (Fig. 2B). In the spring inoculations, Treatments 2 to 4 also led to yield loss in Hopewell (25 to 36\%); however, only Treatment 3 resulted in a significant yield loss in Truman (10\%) compared with the control.

Inoculation with BMV also induced statistically significant $(P<$ 0.05 ) reductions in test weight, TSW, and kernel diameter compared with the controls in most cultivars in both field seasons (Table 2). For test weight, both the magnitude and significance of the treatment effect varied with inoculation timing and cultivar (i.e., the interaction was statistically significant) in both years. Averaged across blocks, mean test weights ranged from 747 to $779 \mathrm{~kg} / \mathrm{m}^{3}$ for Cooper, from
738 to $766 \mathrm{~kg} / \mathrm{m}^{3}$ for Freedom, from 738 to $782 \mathrm{~kg} / \mathrm{m}^{3}$ for Hopewell, and from 783 to $797 \mathrm{~kg} / \mathrm{m}^{3}$ for Truman in 2016 and from 723 to $796 \mathrm{~kg} / \mathrm{m}^{3}$ for Hopewell and from 746 to $800 \mathrm{~kg} / \mathrm{m}^{3}$ for Truman in 2017. For Freedom, Hopewell, and Cooper, all inoculated plots had significantly lower mean test weights than the noninoculated control in 2016; however, for Truman only, Treatments 3 and 4 showed a significant difference compared with the check (in Fig. 2C, only means for Hopewell and Truman are shown). Similar trends were observed in 2017, with all inoculation treatments resulting in significantly lower mean test weight for Hopewell, but only Treatments 1 and 4 resulted in significantly lower means than the control for Truman (Fig. 2D). Treatment 1 (particularly in 2017) and
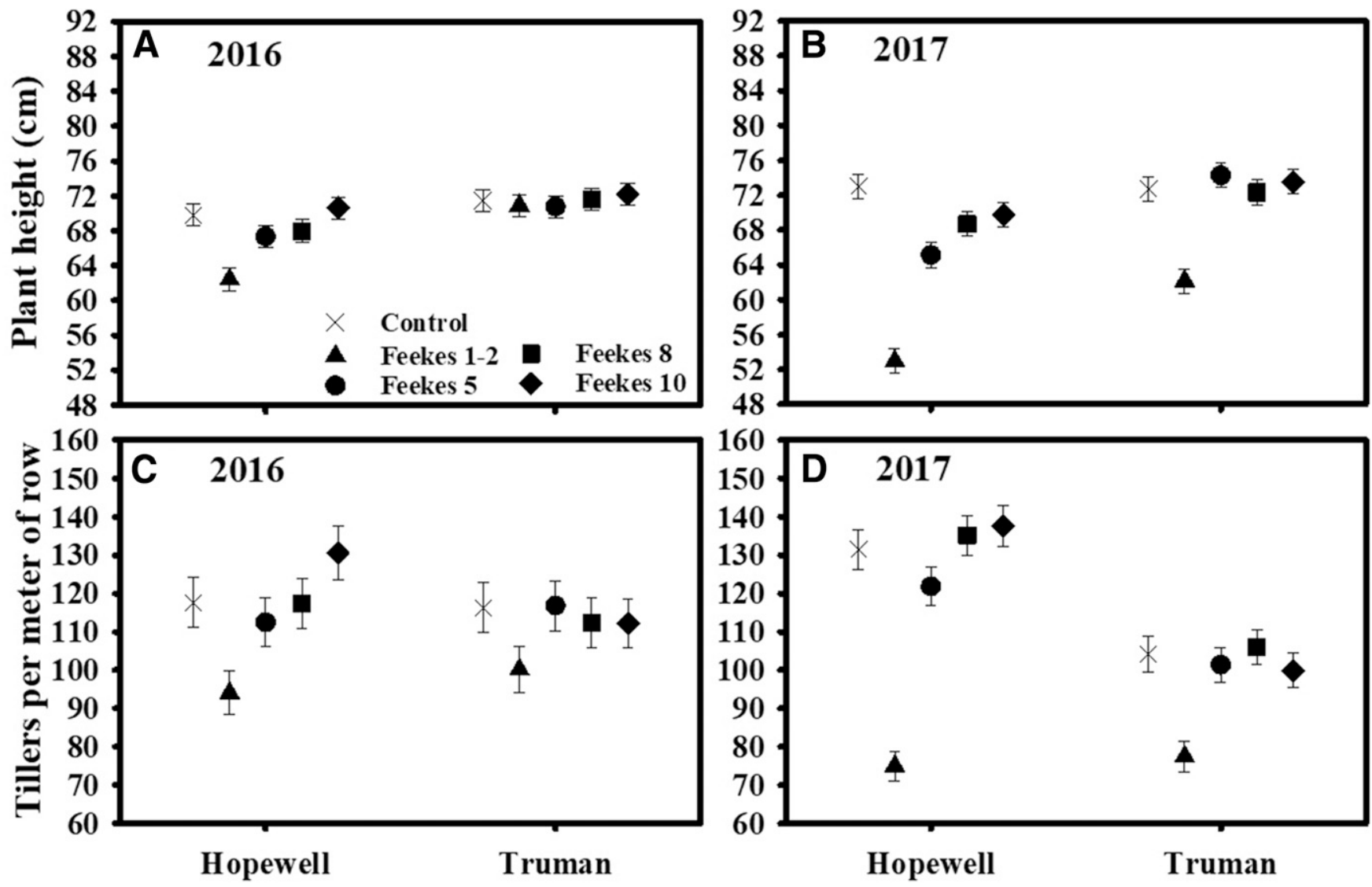

Fig. 1. A and B, Mean plant height and $C$ and D, tiller count for soft red winter wheat cultivars Hopewell and Truman after inoculation with the Ohio isolate of brome mosaic virus in the field. Experiments were conducted in A and C, 2016 and B and D, 2017. The cultivars were either inoculated at Feekes 1 to 2 (Treatment 1), Feekes 5 (Treatment 2), Feekes 8 (Treatment 3), or Feekes 10 (Treatment 4) or left noninoculated (X). Error bars are standard errors of the means.

Table 2. $F$ statistics and probability values from linear mixed model analyses of the effects of wheat cultivar and brome mosaic virus inoculation treatment on soft red winter wheat grain yield and yield components from field experiments conducted in Ohio during the 2016 and 2017 growing seasons $^{\mathrm{a}}$

\begin{tabular}{|c|c|c|c|c|c|c|c|c|}
\hline \multirow[b]{2}{*}{ Year and factors ${ }^{b}$} & \multicolumn{2}{|c|}{ Grain yield } & \multicolumn{2}{|c|}{ Test weight } & \multicolumn{2}{|c|}{ Diameter } & \multicolumn{2}{|c|}{ Seed weight } \\
\hline & $F$ & $P$ value & $F$ & $P$ value & $F$ & $P$ value & $F$ & $P$ value \\
\hline \multicolumn{9}{|l|}{2016} \\
\hline VAR & 39.53 & $<0.001$ & 214.22 & $<0.001$ & 83.09 & $<0.001$ & 143.49 & $<0.001$ \\
\hline TRT & 29.49 & $<0.001$ & 23.55 & $<0.001$ & 2.10 & 0.144 & 13.68 & $<0.001$ \\
\hline VAR $\times$ TRT & 4.94 & $<0.001$ & 5.46 & $<0.001$ & 3.06 & 0.005 & 4.51 & $<0.001$ \\
\hline FDK & 4.55 & 0.038 & 0.48 & 0.491 & 23.66 & $<0.001$ & 15.25 & $<0.001$ \\
\hline \multicolumn{9}{|l|}{2017} \\
\hline VAR & 25.36 & 0.007 & 177.05 & $<0.001$ & 577.56 & $<0.001$ & 381.66 & $<0.001$ \\
\hline TRT & 153.20 & $<0.001$ & 48.86 & $<0.001$ & 59.83 & $<0.001$ & 128.95 & $<0.001$ \\
\hline VAR $\times$ TRT & 14.68 & $<0.001$ & 4.76 & 0.003 & 2.48 & 0.064 & 8.19 & $<0.001$ \\
\hline
\end{tabular}

${ }^{a}$ Measures of crop yield and yield components are shown. Grain yield indicates the total grain harvested (in kilograms per hectare), test weight indicates the grain weight per unit volume (in kilograms per cubic meter), diameter indicates the mean diameter of individual kernels (millimeters), and seed weight indicates the thousand-seed weight (in grams).

b VAR indicates the soft red winter wheat cultivars that were tested in the experiment; TRT indicates the growth stage of virus inoculation, including noninoculated checks; and FDK indicates the percentage of Fusarium-damaged kernels, a covariate used to adjust for the effect of Fusarium head blight in 2016. 
Treatment 4 (particularly in 2016) resulted in the greatest percentage reductions in mean test weight relative to the control.

Similar trends to those observed for test weight were observed for TSW and kernel diameter in both years (Fig. 3). Both main and interaction effects were significant for TSW, and except for inoculation timing main effect in 2016, all main and interaction effects were significant or marginally significant for kernel diameter (Table 2). Although all treatments reduced TSW and kernel diameter for Hopewell in both years, Treatments 1 and 4 consistently induced the greatest reductions compared with the other inoculation treatments (Fig. 3). For Truman, the only significant reduction in TSW and kernel diameter occurred for Treatment 1 in 2017 (Fig. 3 B and D).

\section{Discussion}

BMV is known as a model for RNA virus biology, but little information has been previously reported regarding its economic impact on wheat production. Previous studies on the effects of this virus on wheat yield have been primarily restricted to greenhouse experiments, which indicated that BMV can reduce plant height, kernel weight, and number of kernels per spike (Pocsai 1987; Tošić 1971). This 2-year study is the first to carefully examine the potential impact of BMV-OH on wheat development and production under field conditions. Our results consistently showed that BMV-OH infection at both early and late growth stages led to substantial yield loss in multiple SRWW varieties under different environmental conditions. This suggests that $\mathrm{BMV}-\mathrm{OH}$ may significantly impact wheat production in Ohio, particularly in fields with high incidence of infection (Hodge et al. 2017). Our unquantified symptom observations also suggest that asymptomatic infections as well as those associated with mild to severe chlorotic and mosaic symptoms may all lead to substantial yield reduction.
Our results suggest that BMV has the potential to cause significant economic losses as shown under experimental conditions. For instance, in 2017, we observed an average yield of 5,458 kg/ha with a test weight of $796 \mathrm{~kg} / \mathrm{m}^{3}$ in nontreated plots of Hopewell, which on a 40-ha field at a grain price of U.S. $\$ 184 \mathrm{MT}^{-1}$, would lead to an estimated gross cash income of U.S. $\$ 40,258$ for the producer. In that same year, the average yield from plots of Hopewell inoculated with BMV at Feekes 1 to 2 was $2,094 \mathrm{~kg} / \mathrm{ha}$ (a $61 \%$ reduction relative to the control) with an average test weight of $723 \mathrm{~kg} / \mathrm{MT}$. On a 40-ha field, at a discounted grain price of U.S. $\$ 177.7 \mathrm{MT}^{-1}$ (a U.S. $\$ 6.30 \mathrm{MT}^{-1}$ price discount) owing to low test weight (Salgado et al. 2011), a $61 \%$ yield reduction because of BMV-OH infection would cause an estimated loss of U.S. $\$ 25,302$ to the producer. Additionally, BMV-OH reduced both plant height and tiller count, which likely resulted in a reduction in total straw yield and consequently, an important source of income for the producer (Austin et al. 1977; Donaldson et al. 2001). This could be an additional component of the economic impact of BMV on wheat production. Test weight is often used as a proxy indicator of SRWW quality and value. Low test weight is often correlated with reduced grain and flour protein content (Schuler et al. 1994), which in turn, is associated with reduced flour quality that changes the end use product (Gaines 1985), leading to potential economic impact to buyers of grain or flour.

The BMV-OH isolate was found to share high nucleotide sequence identity with the BMV-Fescue isolate and other known isolates of BMV. BMV-OH has the highest nucleotide sequence identity with other North American isolates of BMV, including BMV-Fescue, and BMV-M2. Other isolates of BMV, including BMV-M2, Polish isolates BMV-Sr and BMV-Sz, and a Canadian isolate, have been reported to infect cowpea and soybean (De Jong and Ahlquist 1995; Díaz-Cruz et al. 2017; Trzmiel et al. 2016). De Jong and Ahlquist (1995) showed that four amino acid substitutions in the BMV-M2 movement protein (E59Q, S89P, S297G, and
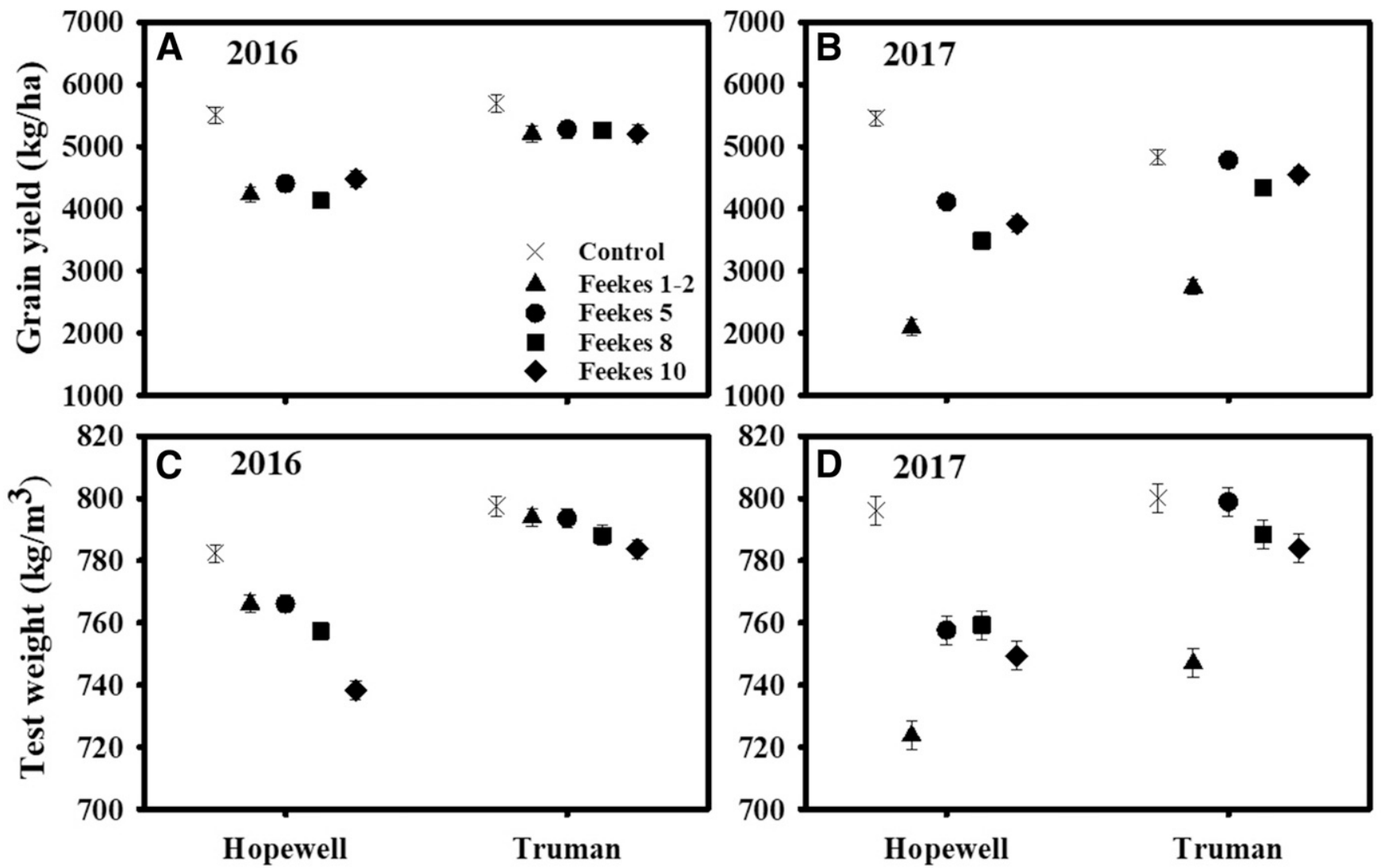

Fig. 2. $A$ and $B$, Mean grain yield and $C$ and $D$, test weight for soft red winter wheat cultivars Hopewell and Truman after inoculation with an Ohio isolate of brome mosaic virus in field experiments conducted in $A$ and C, 2016 and B and D, 2017. The cultivars were either inoculated at Feekes 1 to 2 (Treatment 1), Feekes 5 (Treatment 2), Feekes 8 (Treatment 3), or Feekes 10 (Treatment 4 ) or left noninoculated $(X)$. Error bars are standard errors of the means. 
T299S) were required to systemically infect cowpea. Although our BMV-OH (and BMV-Fescue) isolate shares only two of these amino acid substitutions with BMV-M2 (S89P and T299S), it was still able to systemically infected cowpea and soybean in our experiments. This expanded host range may place SRWW in Ohio at a higher risk for infection, because nearby weed species as well as rotation crops, such as corn and soybean, may all serve as potential virus reservoirs. As both a monocot- and dicot-infecting isolate, the potential for BMV-OH to limit production of the three major field crops (corn, soybean, and wheat) grown in Ohio merits additional examination.

Our results showed that BMV-OH consistently reduced grain yield and affected crop growth in the four SRWW cultivars evaluated. However, there was clear evidence of cultivar-specific responses to $\mathrm{BMV}-\mathrm{OH}$ that have not been previously described or explored. For instance, there were clear differences in the effect of BMV-OH on Hopewell and Truman in terms of plant height, tiller count, and yield response in both years, despite similarities in the mean levels of incidence of infection between the cultivars. This suggests that Hopewell may be more susceptible to the negative effects of BMV-OH infection than Truman. Hopewell (as well as Cooper and Freedom) consistently suffered substantial yield loss after inoculation at each of the targeted growth stages, whereas for Truman, the average yield loss was much lower. Genotypes of fescue that were not susceptible to BMV infection have been described (Mian et al. 2005), and our study suggests that at least partial quantitative resistance may exist in the SRWW germplasm. However, additional research would be needed to specifically map and characterize resistance to BMV-OH in SRWW. Hopewell and Truman could be used as "susceptible" and "resistant" references against which other cultivars or breeding lines would be compared and classified.

The magnitude of the effects of BMV-OH on growth and yield responses was dependent on the timing of inoculation/infection and growing conditions. Inoculation at Feekes 1 to 2 had greater impact on yield than inoculation at other growth stages, and this effect was very pronounced in the 2017 season. This indicates that, under the right set of growing conditions, fall infections with BMV-OH have a greater potential to impact SRWW than infections at later growth stages. In both years, inoculation at Feekes 1 to 2 and Feekes 10 had the greatest impact on yield components across cultivars, indicating that the impact of BMV is different when infection occurs shortly after plant emergence or just before heading than it is when infection occurs between green up and flag leaf emergence. This observation was further shown by the growth stage-dependent symptoms expressed by the plants: inoculation at Feekes 1 to 2 induced mosaic symptoms and severe stunting, and Feekes 5 infection induced flag leaf chlorosis, whereas Feekes 8 to 10 infection did not induce symptoms distinguishable from the controls.

Based on the observed symptoms, incidence of infection, and growth stage-dependent responses in yield components, we hypothesize that different mechanisms of yield reduction may be associated with the different times of infection. Inoculation at Feekes 1 to 2 induced a characteristic mosaic symptom associated with severe stunting and reduced tiller population in both years. It is well known that stand count and plant biomass directly influence yield and yield components. For plots infected with BMV at Feekes 1 to 2, a reduction in the number of spike-bearing tillers per meter of row (stand count) likely led to a reduction in the mass and volume of grain produced per unit area (Guitard et al. 1961; Nerson 1980). Additionally, a reduction in the amount of green leaf tissue per unit area (owing to retarded crop development, poor stands, and mosaic symptoms) may have decreased the photosynthetic efficacy of severely affected plots, leading to reduced kernel size and weight of the harvested grain (Miralles and Slafer 1995; Simpson 1968). It is plausible that the relatively high levels of yield loss observed in 2017 after inoculation at
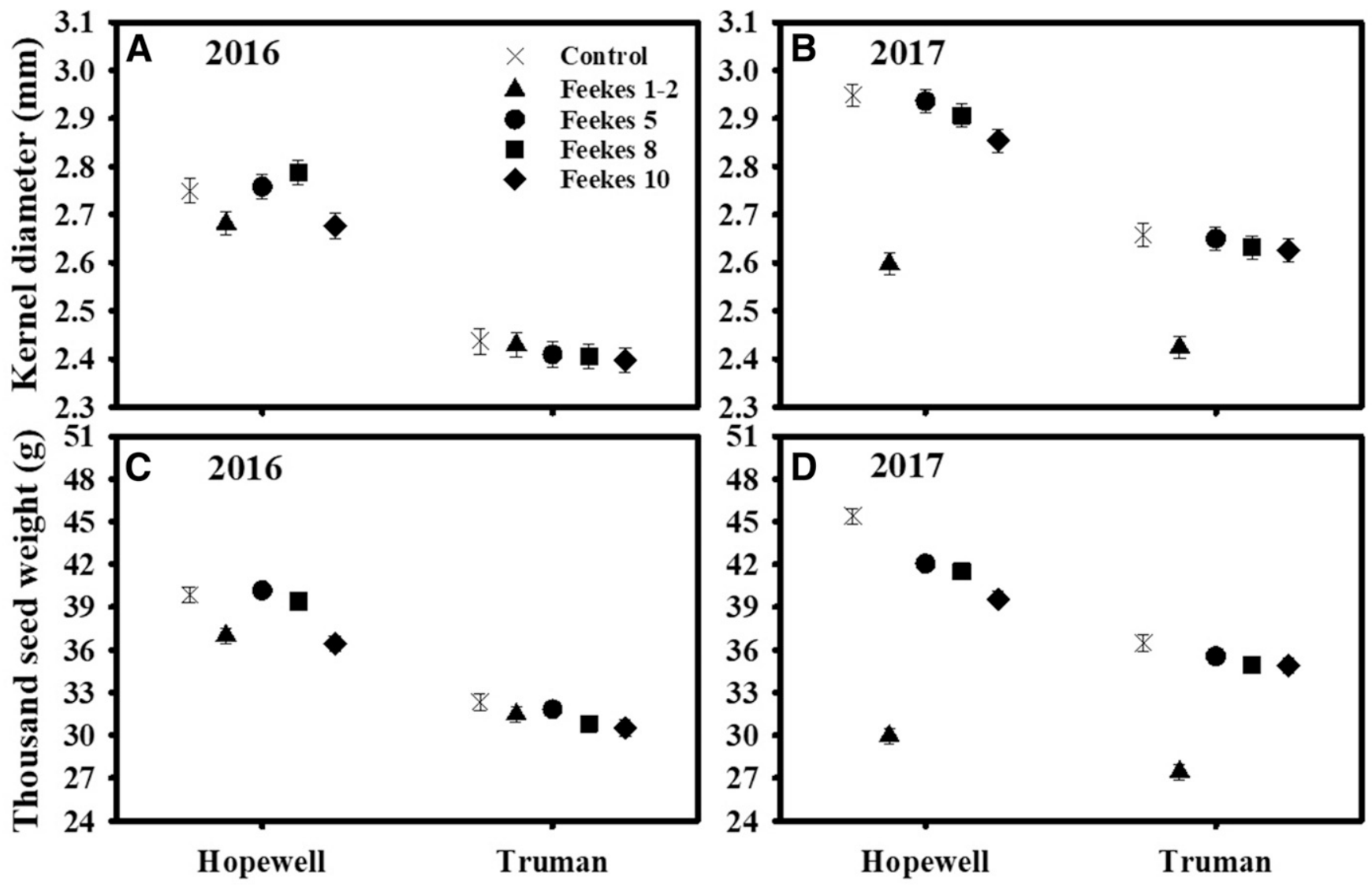

Fig. 3. A and B, Mean kernel diameter and C and D, thousand-seed weight for soft red winter wheat cultivars Hopewell and Truman after inoculation with an Ohio isolate of brome mosaic virus in field experiments conducted in A and C, 2016 and B and D, 2017. The cultivars were either inoculated at Feekes 1 to 2 (Treatment 1), Feekes 5 (Treatment 2 ), Feekes 8 (Treatment 3 ), or Feekes 10 (Treatment 4 ) or left noninoculated $(X)$. Error bars are standard errors of the means. 
Feekes 1 to 2 may have been because of a greater effect on tiller height and count on grain production per unit area in that year than in 2016. This effect may be because of an interaction between reduced winter hardiness of fall-infected plants and harsh environmental conditions. Our weather data showed that there were more days below $0{ }^{\circ} \mathrm{C}$ in 2016 to 2017 from October to December and from April to June than in 2015 to 2016, which were trimesters during which there was probably minimal snow cover to protect wheat from harsh conditions. Other cereal viruses, including BYDV and WSSMV, have been reported to reduce winter hardiness of wheat when there was insufficient snow cover (Cisar et al. 1982; Paliwal and Andrews 1979).

Inoculation at the later growth stages did not impact tiller height and stand count as severely, but yield loss was still observed. Chlorosis was observed on the emergent flag leaves in plots inoculated at Feekes 5, which visually appeared more severe in Hopewell than in Truman. Substantial yield reduction occurred for Hopewell from inoculation at Feekes 5, but only slight reduction occurred for Truman. The severity of chlorosis associated with inoculation at Feekes 5 was not formally quantified; however, we hypothesize that the yield reduction caused by inoculation at Feekes 5 was owing to a specific cultivar by inoculation timing interaction that induced chlorosis of the flag leaves. Chlorosis reduces the photosynthetic area of the flag leaves, thus reducing the total photosynthetic output of the plant and plot (or field). Because kernel size and weight have been previously shown to be correlated to photosynthetic area of the flag leaf during grain fill, the reduction in yield observed from inoculation at Feekes 5 was likely associated with a reduction in green, healthy leaf area because of chlorosis (Gooding et al. 2000; Simpson 1968).

Inoculation at Feekes 8 and 10 did not induce any symptoms distinguishable from the controls but still resulted in substantial reductions in yield in Hopewell (Cooper and Freedom) and slight reductions in Truman. The nonsignificant differences in yield (and yield components) between mock inoculations and the noninoculated checks during 2017 eliminated the possibility that the observed response to inoculations at late growth stages was because of injuries caused by the mechanical inoculation process. Additionally, the fact that BMV was detected from tissue collected from plots inoculated at Feekes 8 and 10 showed that the virus successfully infected the flag leaves after late-spring inoculations. Yield reductions from inoculation at Feekes 8 and 10 for Hopewell were associated with corresponding reductions in test weight, thousand-kernel weight, and kernel diameter but little to no reduction in tiller height or count. The magnitude of these responses in Hopewell was most pronounced from inoculation at Feekes 10 compared with inoculation at Feekes 5 and 8 . Although we can attribute the observed yield reduction to the consistent reduction in yield components, the specific mechanism by which BMV-OH causes these deleterious effects when inoculated at Feekes 8 and 10 is unknown and warrants additional investigation.

Previous studies of wheat viruses have indicated that the greatest impacts occur in fall to early-spring infections and that little impact occurs when wheat is inoculated at later growth stages (Feekes 8+) (Eslick and Afanasiev 1955; Hunger et al. 1992; Miller et al. 2014; Perry et al. 2000). However, our results showed that BMV-OH induced substantial yield reduction at both early and late growth stages. With other cereal viruses, when infection occurred at early growth stages, the virus affected plant development parameters that impacted yield, including tiller count, plant biomass, photosynthetic output, and spike development, which we observed with BMV-OH inoculated at Feekes 1 to 2 and 5 in our study. Because Feekes 8 to 10 inoculations were done after several developmental processes, such as tillering and jointing, were completed and yield components, such as tillers per unit area and number of florets per spike, were determined (Gardner et al. 1985; Large 1954; Waddington et al. 1983), the fact that these late infections still caused yield loss led us to hypothesis that BMV-OH may be inducing yield reduction through other growth stage-dependent mechanisms.

Our demonstration that BMV-OH could lead to yield loss in SRWW at either early or late stages of infection in experimentally inoculated fields still begs the question of whether it does lead to economically significant yield loss in production field settings with natural inoculation, especially because means of BMV spread in these settings are not well demonstrated. Measuring and correctly attributing actual field losses owing to virus infection in uncontrolled commercial fields are always very challenging, with conditions, confounding interactions, and inoculation levels changing by location and year. Our survey results and a few published reports indicate that BMV prevalence varies from year to year and can be detected at up to 25\% incidence in Ohio commercial wheat fields (Hodge et al. 2017), $13 \%$ in Alabama (Srivatsavai 2005), and $44 \%$ in Poland (Papp et al. 1996). Additional investigation is needed to relate the results from our field experiments to natural BMV infections in commercial SRWW fields, including temporal, spatial, and regional changes in incidence; variability in cultivar and virus sequence responses; mode and timing of transmission; and the role of rotation hosts, such as corn and soybean, as reservoirs for BMV under growing conditions in Ohio.

Based on our findings, we conclude that, if BMV becomes highly prevalent, it is capable of seriously impacting SRWW production. Management strategies, such as reducing inoculum and planting tolerant cultivars, are advisable where high incidence of BMV is detected in wheat. However, other management strategies will need to be implemented to target the entire growing season, not just the fall and early spring. The virus will be able to induce yield loss not only from initial fall infections that spread from nearby green hosts but also, from secondary spread that occurs during the spring through maturity. These effects can be controlled or minimized through the development and use of resistant cultivars; however, screening for resistance will need to be done at both early and late growth stages. A better understanding of the specific growth stage- and cultivar-dependent mechanisms leading to yield reduction could improve our ability to screen for resistance and predict cultivar susceptibility to BMV using molecular markers. Management solutions need to be investigated while BMV incidence is reported to be relatively low so that they can be deployed should virus prevalence and incidence within fields increase regionally.

\section{Acknowledgments}

Special thanks to L. Ault and the Snyder Farm crew for assisting with plot establishment and maintenance. We also thank the members of the laboratories of P. A. Paul and L. R. Stewart for their contributions to tissue and data collection and Saranga Wijeratne and the Molecular Cellular Imaging Center for assistance with RNA-Seq data analysis.

\section{Literature Cited}

Ahlquist, P. 1992. Bromovirus RNA replication and transcription. Curr. Opin. Genet. Dev. 2:71-76.

Ahlquist, P., Dasgupta, R., and Kaesberg, P. 1984. Nucleotide sequence of the brome mosaic virus genome and its implications for viral replication. J. Mol. Biol. 172:369-383.

Ahlquist, P., and Janda, M. 1984. cDNA cloning and in vitro transcription of the complete brome mosaic virus genome. Mol. Cell. Biol. 4:2876-2882.

Austin, R. B., Ford, M. A., Edrich, J. A., and Blackwell, R. D. 1977. The nitrogen economy of winter wheat. J. Agric. Sci. 88:159-167.

Barker, D., Culman, S., Dorrance, A., Fulton, J., Haden, R., Lentz, E., Lindsey, A. Lindsey, L., Loux, M., McCoy, E., Michel, A., Noel, J., Paul, P., Sulc, M. Thomison, P., Tilmon, K., and Witter, J. 2017. Ohio Agronomy Guide, 15th Ed. The Ohio State University, Columbus, $\mathrm{OH}$.

Brakke, M. K. 1987. Virus diseases of wheat. Pages 585-624 in: Wheat and Wheat Improvement. Agronomy Monograph 13. ASA-CSSA-SSSA, Madison, WI

Byamukama, E., Tatineni, S., Hein, G. L., McMechan, J. A., and Wegulo, S. N. 2016. Incidence of wheat streak mosaic virus, triticum mosaic virus, and wheat mosaic virus in wheat curl mites recovered from maturing winter wheat spikes. Plant Dis. 100:318-323.

Campbell, L. G., and Lafever, H. N. 1977. Cultivar by environment Interactions in soft red winter wheat yield tests. Crop Sci. 17:604-608.

Carrigan, L. L., Ohm, H. W., Foster, J. E., and Patterson, F. L. 1981. Response of winter wheat cultivars to barley yellow dwarf virus infection. Crop Sci. 21:377-380.

Chang, P.-G. S., McLaughlin, W. A., and Tolin, S. A. 2011. Tissue blot immunoassay and direct RT-PCR of cucumoviruses and potyviruses from the same NitroPure nitrocellulose membrane. J. Virol. Methods 171:345-351.

Cisar, G., Brown, C. M., and Jedlinski, H. 1982. Effect of fall or spring infection and sources of tolerance of barley yellow dwarf of winter wheat. Crop Sci. 22 474-478. 
Damsteegt, V. D., Gildow, F. E., Hewings, A. D., and Carroll, T. W. 1992. A clone of the Russian wheat aphid (Diuraphis noxia) as a vector of barley yellow dwarf, barley stripe mosaic, and brome mosaic viruses. Plant Dis. 76:1155-1160.

De Jong, W., and Ahlquist, P. 1995. Host-specific alterations in viral RNA accumulation and infection spread in a brome mosaic virus isolate with an expanded host range. J. Virol. 69:1485-1492.

Díaz-Cruz, G. A., Smith, C. M., Wiebe, K. F., Charette, J. M., and Cassone, B. J. 2017. First report of brome mosaic virus infecting soybean, isolated in Manitoba, Canada. Plant Dis. 2:460.

Ding, X. S., Boydston, C. M., and Nelson, R. S. 2001. Presence of brome mosaic virus in barley guttation fluid and its association with localized cell death response. Phytopathology 91:440-448.

Ding, X. S., Schneider, W. L., Chaluvadi, S. R., Mian, M. R., and Nelson, R. S. 2006. Characterization of a brome mosaic virus strain and its use as a vector for gene silencing in monocotyledonous hosts. Mol. Plant-Microbe Interact. 19:1229-1239.

Donaldson, E., Schillinger, W. F., and Dofing, S. M. 2001. Straw production and grain yield relationships in winter wheat. Crop Sci. 41:100-106.

Eslick, R. F., and Afanasiev, M. M. 1955. Influence of time of infection with barley stripe mosaic on symptoms, plant yield, and seed infection of barley. Plant Dis. 39:722-724.

Gáborjányi, R., and Szabolcs, J. 1987. Brome mosaic virus transmission by cereal leaf beetle (Oulema melanopus, Coleoptera,Chrysomelidae). Cereal Res. Commun. 15:259-264.

Gaines, C. S. 1985. Associations among soft wheat flour particle size, protein content, chlorine response, kernel hardness, milling quality, white layer cake volume, and sugar-snap cookie spread. Cereal Chem. 62:290-292.

Gardner, J. S., Hess, W. M., and Trione, E. J. 1985. Development of the young wheat spike: A sem study of Chinese spring wheat. Am. J. Bot. 72:548-559.

Gbur, E. E., Stroup, W. W., McCarter, K. S., Durham, S., Young, L. J., Christman, M., West, M., and Kramer, W. 2012. Analysis of Generalized Linear Mixed Models in the Agricultural and Natural Resources Sciences. Crop Science Society of America, Madison, WI.

Gibson, R. W., and Kenten, R. H. 1978. The occurrence of brome mosaic virus in Britain. Plant Pathol. 27:66-67.

Gooding, M. J., Dimmock, J. P. R. E., France, J., and Jones, S. A. 2000. Green leaf area decline of wheat flag leaves: The influence of fungicides and relationships with mean grain weight and grain yield. Ann. Appl. Biol. 136:77-84.

Green, A. J., Berger, G., Griffey, C. A., Pitman, R., Thomason, W., Balota, M., et al. 2012. Genetic yield improvement in soft red winter wheat in the eastern United States from 1919 to 2009. Crop Sci. 52:2097-2108.

Guitard, A. A., Newman, J. A., and Hoyt, P. B. 1961. The influence of seeding rate on the yield and the yield components of wheat, oats and barley. Can. J. Plant Sci. 41:751-758.

Haber, S. 1989. Brome mosaic virus isolated in Manitoba, Canada. Plant Dis. 73: 195.

Hamilton, R. I. 1961. Properties of brome mosaic virus and its related antigens. Virology 15:452-464.

Hodge, B., Stewart, L., and Paul, P. 2017. The prevalence of viruses in Ohio wheat fields. American Phytopathological Society Annual Meeting. San Antonio, TX.

Hunger, R., Sherwood, J., Evans, C., and Montana, J. 1992. Effects of planting date and inoculation date on severity of wheat streak mosaic on hard red winter wheat cultivars. Plant Dis. 76:1056-1060.

Janda, M., and Ahlquist, P. 1993. RNA-dependent replication, transcription, and persistence of brome mosaic virus RNA replicons in S. cerevisiae. Cell 72: P961-P970.

Jeżewska, M., Trzmiel, K., and Zarzyńska-Nowak, A. 2018. Detection of infectious brome mosaic virus in irrigation ditches and draining strands in Poland. Eur. J. Plant Pathol. 1:1-8.

Kao, C. C., and Sivakumaran, K. 2000. Brome mosaic virus, good for an RNA virologist's basic needs. Mol. Plant Pathol. 1:91-97.

Kriss, A. B., Paul, P. A., and Madden, L. V. 2012. Characterizing heterogeneity of disease incidence in a spatial hierarchy: A case study from a decade of observations of fusarium head blight of wheat. Phytopathology 102:867-877.

Lackermann, K. V., Conley, S. P., Gaska, J. M., Martinka, M. J., and Esker, P. D. 2011. Effect of location, cultivar, and diseases on grain yield of soft red winter wheat in Wisconsin. Plant Dis. 95:1401-1406.

Lane, L. C. 1974. The bromoviruses. Adv. Virus Res. 19:151-220.

Large, E. C. 1954. Growth stages in cereals illustration of the Feekes scale. Plant Pathol. 3:128-129.

Lee, C. D., and Herbek, J. H. 2012. Winter wheat yield response to wide rows varies by year in the southern Ohio River Valley. Crop Manag. 11:1-5.

Littell, R. C., Milliken, G. A., Stroup, W. W., Wolfinger, R. D., and Schabenberger, O. 2006. SAS for Mixed Models, 2nd Ed. SAS Institute, Cary, NC.

Louie, R., Gordon, D. T., Knoke, J., Gingery, R., Bradfute, O., and Lipps, P. 1982. White line mosaic virus in Ohio. Plant Dis. 66:167-170.

Louie, R., and Knoke, J. 1991. Detection of maize dwarf mosaic onset in Ohio. Phytopathology 81:760-765.

Louie, R., Seifers, D. L., and Bradfute, O. E. 2006. Isolation, transmission and purification of the High Plains virus. J. Virol. Methods 135:214-222.

Lucas, R. W., Larson, S. B., and McPherson, A. 2002. The crystallographic structure of brome mosaic virus. J. Mol. Biol. 317:95-108.
Mayer, K., Rogers, J., Dolezel, J., Pozniak, C., Eversole, K., and Feuillet, C. 2014 A chromosome-based draft sequence of the hexaploid bread wheat (Triticum aestivum) genome. Science 345:1251788.

Mian, M. R., Zwonitzer, J. C., Hopkins, A. A., Ding, X. S., and Nelson, R. S. 2005 Response of tall fescue genotypes to a new strain of brome mosaic virus. Plant Dis. 89:224-227.

Miller, W. A., and Rasochová, L. 1997. Barley yellow dwarf viruses. Annu. Rev. Phytopathol. 35:167-190.

Miller, Z., Menalled, F., Ito, D., Moffet, M., and Burrows, M. 2014. Impacts of crop variety and time of inoculation on the susceptibility and tolerance of winter wheat to wheat streak mosaic virus. Plant Dis. 98 1060-1065.

Miralles, D. J., and Slafer, G. A. 1995. Yield, biomass and yield components in dwarf, semi-dwarf and tall isogenic lines of spring wheat under recommended and late sowing dates. Plant Breed. 114:392-396.

Nerson, H. 1980. Effects of population density and number of ears on wheat yield and its components. Field Crops Res. 3:225-234

Oleson, B. T. 1996. Pages 1-10 in: World Wheat Production, Utilization, and Trade. Springer Science and Business Media, Berlin, Germany.

Paliwal, Y. C., and Andrews, C. J. 1979. Effects of barley yellow dwarf and wheat spindle streak mosaic viruses on cold hardiness of cereals. Can. J. Plant Pathol $1: 71-75$

Papp, M., Mesterházy, Á., Vasdinyei, R., and Gáborjányi, R. 1996. Mixed virus infection of wheat in South-East Hungary in 1994 and 1995. Cereal Res. Commun. 179-182.

Perry, K. L., Kolb, F. L., Sammons, B., Lawson, C., Cisar, G., and Ohm, H. 2000 Yield effects of barley yellow dwarf virus in soft red winter wheat. Phytopathology 90:1043-1048.

Pocsai, E. 1987. Effect of brome mosaic virus infection on the plant height and weight of cereals at their early stages of growth. Cereal Res. Commun. 15: 167-174.

Rao, A. L. N., and Grantham, G. L. 1995. Biological significance of the seven amino-terminal basic residues of brome mosaic virus coat protein. Virology 211:42-52.

Richer, E., and Lindsey, L. E. 2016. On-farm investigation of seeding rate for wide-row wheat production in northwest Ohio. Crop Forage Turfgrass Manage. 2:1-3

Rybicki, E. P., and Wechmar, M. B. 1982. Characterization of an aphid-transmitted virus disease of small grains. J. Phytopathol. 103:306-322.

Salgado, J. D., Lindsey, L. E., and Paul, P. A. 2017. Effects of row spacing and nitrogen rate on wheat grain yield and profitability as influenced by diseases. Plant Dis. 101:1998-2011.

Salgado, J. D., Madden, L. V., and Paul, P. A. 2015. Quantifying the effects of fusarium head blight on grain yield and test weight in soft red winter wheat. Phytopathology 105:295-306

Salgado, J. D., Wallhead, M., Madden, L. V., and Paul, P. A. 2011. Grain harvesting strategies to minimize grain quality losses due to fusarium head blight in wheat. Plant Dis. 95:1448-1457.

Scholthof, K. B. G., Adkins, S., Czosnek, H., Palukaitis, P., Jacquot, E., Hohn, T., Hohn, B., Saunders, K., Candresse, T., Ahlquist, P., Hemenway, C., and Foster, G. D. 2011. Top 10 plant viruses in molecular plant pathology. Mol. Plant Pathol. 12:938-954.

Schuler, S. F., Bacon, R. K., and Gbur, E. E. 1994. Kernel and spike character influence on test weight of soft red winter wheat. Crop Sci. 34:1309-1313

Shepherd, R. J., Richins, R. D., Duffus, J. E., and Handley, M. K. 1987. Figwort mosaic virus: Properties of the virus and its adaption to a new host Phytopathology 77:1668-1673.

Simpson, G. M. 1968. Association between grain yield per plant and photosynthetic area above the flag-leaf node in wheat. Can. J. Plant Sci. 48 253-260.

Slykhuis, J. T. 1976. Virus and virus-like diseases of cereal crops. Annu. Rev. Phytopathol. 14:189-210.

Sõmera, M., Gantsovski, M., Truve, E., and Sooväli, P. 2016. First report of brome mosaic virus in wheat in Estonia. Plant Dis. 100:2175.

Srivatsavai, V. 2005. Identification, distribution and vector biology of brome mosaic virus of wheat in Alabama. Masters dissertation. Auburn University, Auburn, AL.

Stewart, L. R., Paul, P. A., Qu, F., Redinbaugh, M. G., Miao, H., Todd, J., and Jones, M. 2013. Wheat mosaic virus (WMoV), the causal agent of high plains disease, is present in Ohio wheat fields. Plant Dis. 97:1125.

Stewart, L. R., Teplier, R., Todd, J. C., Jones, M. W., Cassone, B. J., Wijeratne, S., and Redinbaugh, M. G. 2014. Viruses in maize and johnsongrass in southern Ohio. Phytopathology 104:1360-1369.

Stroup, W. 2013. Pages 335-369 in: Generalized Linear Mixed Models: Modern Concepts, Methods, and Applications. Taylor and Francis Group, Boca Raton, FL.

Todd, J. C., Ammar, E.-D., Redinbaugh, M. G., Hoy, C., and Hogenhout, S. A 2010. Plant host range and leafhopper transmission of maize fine streak virus. Phytopathology 100:1138-1145.

Tošić, M. 1971. Virus diseases of wheat in Serbia. Some changes in wheat plants infected with wheat streak mosaic virus (WSMV) and brome mosaic virus (BMV). Eur. J. Phytopathol. 71:327-340. 
Trzmiel, K., Zarzyńska-Nowak, A., Lewandowska, M., and Szydło, W. 2016. Identification of new brome mosaic virus (BMV) isolates systemically infecting Vigna unguiculata L. Eur. J. Plant Pathol. 145:233-238.

Turner, C., and Morris, B. 2017. Ohio agricultural statistics 2016-2017 annual bulletin. Ohio Dep. Agric. U.S. Dep. Agric. 1:10-18.

Urbanavičienè, L., and Žižyte, M. 2012. Identification of brome mosaic virus in cocksfoot (Dactylis glomerata L.) and meadow fescue (Festuca pratensis Huds.) in Lithuania. Žemdirb. Agric. 99:167-172.

USDA ERS. 2018. World Agricultural Supply and Demand Estimates. U.S. Economic Research Service.

USDA NASS. 2017. Small Grains 2017 Summary. U.S. Department of Agriculture National Agricultural Statistics Service.
USDA NASS. 2018. Crop Values 2017 Summary. U.S. Department of Agriculture National Agricultural Statistics Service.

Velandia, M., Rejesus, R. M., Jones, D. C., Price, J. A., Workneh, F., and Rush, C. M. 2010. Economic impact of wheat streak mosaic virus in the Texas high plains. Crop Prot. 29:699-703

von Wechmar, M. B., Kaufmann, A., Desmarais, F., and Rybicki, E. P. 1984 Detection of seed-transmitted brome mosaic virus by ELISA, radial immunodiffusion and immunoelectroblotting tests. J. Phytopathol. 109:341-352.

Von Wechmar, M. H. V., and Barbara Van Regenmortel, M. 1966. Virus diseases' of cereals in South Africa. I. Bromegrass mosaic virus. S. Afr. J. Agric. Sci. 9:443-452.

Waddington, S. R., Cartwright, P. M., and Wall, P. C. 1983. A quantitative scale of spike initial and pistil development in barley and wheat. Ann. Bot. 51:119-130. 